\title{
Trade OPENNESS AND FOREIGN DIRECT INVESTMENT IN AfRICA
}

\author{
Tonia Kandiero ${ }^{1}$ \\ Global Development Policy, National Treasury \\ Margaret Chitiga \\ Department of Economics, University of Pretoria
}

\begin{abstract}
Africa's share of foreign direct investment (FDI) has lagged behind other regions in the world, despite a sharp increase in FDI inflows to the region in 2001. Factors contributing to this circumstance include perceptions of high corruption, weak governance and poor infrastructure. The motivation of this paper is to investigate the impact of openness to trade on the FDI inflow to Africa. In addition to economy-wide trade openness, we also analyse the impact on FDI of openness in manufactured goods, primary commodities and services. The empirical work uses cross-country data from selected African countries observed over four periods: 1980-1985, 1985-1990, 19901995 and 1995-2001. We find that the FDI to GDP ratio responds well to increased openness in the whole economy and in the services sector in particular.
\end{abstract}

JEL F11, 41

\section{1}

\section{Introduction}

According to the World Investment Report 2002 (UNCTAD, 2002), Africa's share of total foreign direct investment (FDI) increased from $\$ 9$ billion in 2000 to $\$ 18.5$ billion in 2001 . This escalation in FDI flows was primarily due to a rise in FDI in South Africa and Morocco. In the global context, the share of world FDI inflows to Africa rose from 1 per cent in 2000 to 2 per cent in 2001 (UNCTAD, 2002). Factors contributing to this lag in FDI flows to Africa relative to the world include perceptions of high corruption, weak governance and poor infrastructure, among other disadvantages. Nonetheless, resource-rich countries like Algeria, Angola, Egypt, Nigeria and South Africa continue to attract FDI. ${ }^{2}$ In addition to resource endowments, economic reform has also contributed to Mozambique, Tanzania, Botswana, Morocco and Uganda's becoming attractive FDI destinations (Basu \& Srinivsan, 2002). Economic theory suggests that foreign savings can be beneficial in many ways. For example, FDI inflows stimulate capital accumulation by adding to domestic savings and raising the recipient economy's efficiency through improving resource allocation, provoking competition, improving human capital, deepening domestic financial markets and reducing local capital costs (Todaro, 2002: 582). In the particular case of FDI from South Africa in other parts of Africa, firms play a major role in providing much needed financing resources for infrastructure development and rehabilitation of economies ((Akinboade \& Lalthapersad, 2005). All these factors contribute to economic growth ${ }^{3}$.

The motivation of this paper is to investigate the impact of openness to trade on the flow of FDI into Africa. In addition to economy-wide trade openness, the study also empirically investigates the impact on FDI of openness in manufactured goods, primary commodities and services. We adhere to the notion that markets that are more open are more likely to create significant economic static welfare gains through more efficient allocation of resources than are less open markets. With efficient use of resources, dynamic gains are 
expected in the longer term with enhanced investment, productivity and growth. This economically conducive environment is likely to attract foreign businesses, causing FDI inflows to increase (Kumar, 2002: 33). Several other studies have also looked at the impact of openness on FDI. ${ }^{4}$ Our paper is along the lines of the study by Asiedu (2002), where econometric techniques are used to explore whether factors that affect FDI in developing countries affect countries in sub-Saharan Africa differently. The results indicate that: (i) a higher return on investment and better infrastructure have a positive impact on FDI in countries in non sub-Saharan Africa, but have no significant impact on FDI in sub-Saharan Africa; (ii) openness to trade promotes FDI in sub-Saharan Africa and countries in non-sub-Saharan Africa, however, the marginal benefit from increased openness is less for sub-Saharan Africa. Our study differs from this paper in four ways: (i) our paper covers more countries in Africa; (ii) our data covers four periods, 1980-1985, 19851990, 1990-1995 and 1995-2001, which is a larger coverage than Asiedu's study; (iii) we control for openness in the primary, manufacturing and services sectors; and (iv) we control for the most common problems in studies across countries, namely individual country effects and endogeneity. In the last step, treating countryindividual effects incorrectly, for example, in technology or tastes, may give rise to omitted variable bias. In the case of endogeneity, there is a strong theoretical argument that at least a subset of the explanatory variables should be expected to be endogenous. Therefore our approach applies differencing of variables to deal with individual countries, and instrument the independent variables using lagged variables effects to address the endogeneity problem ${ }^{5}$. Following Asiedu, we do not attempt to provide any novelty in terms of the theoretical analysis of how openness affects FDI. Thus, the importance of this paper lies in its empirical results.

Our paper is divided into 5 sections: section 2 gives a background on FDI and trade openness in Africa; section 3 presents the research methodology and data definition; section 4 discusses results; and section 5 offers conclusions and recommendations for the way forward.
Background

\subsection{Foreign direct investment}

There are several reasons why foreign firms choose to invest away from their home countries. Dunning (1993) points to rent-seeking, marketseeking, efficiency-seeking and strategic-asset seeking as factors motivating FDI from most industrialised countries. The rent-seeking accumulation motive involves foreign firms seeking cheaper factors and inputs of production such as primary products. Market-seeking FDI ideally involves foreign firms exporting or opening new markets in host countries in order to boost their sales. This is also another way for firms to get around trade restrictions such as high transport costs and rules of origin. Efficiencyseeking firms aim at using a few countries to serve a larger market. The key motives for efficiency-seeking FDI are location, resource endowment and government regulations. The last motive, strategic-asset seeking, is more concerned with maintaining the foreign firms' international position and competitiveness. In most low-income African countries, FDI is likely to fall in the non-market-seeking category ${ }^{6}$. This is because most non-market FDI goods are produced in the country and exported abroad while in the market-seeking case, goods are produced and sold domestically. Market-seeking FDI thrives in large markets and high-income economies (Asiedu, 2002).

FDI inflows in our sample of sub-Saharan and North African countries increased from $\$ 9$ billion in 2000 to $\$ 18.5$ billion in 2001 (see Table 2 in the appendix). These figures are still considered marginal, given that total FDI inflow to the world amounted to $\$ 735$ billion in 2001 . The net FDI inflows to Africa are concentrated in South Africa, Morocco, Angola and Nigeria, with South Africa having the largest share (39 per cent) of total FDI inflow in the region (see Figure 1 in the appendix). Traditionally, most of the FDI in Africa has been in the primary sectors, particularly oil and mineral extraction business, but FDI inflows in this sector declined from $\$ 5,056$ million in 1998 to $\$ 2,029$ in 2000 . In recent years the services sector has also 
become important in terms of attracting FDI flows (Markusen, Rutherford \& Tarr, 2000). FDI inflows through the services channel are mainly in telecommunications, banking and finance, transport, wholesale and retail trade and business and legal services. FDI to the tertiary sector rose from $\$ 52$ million to $\$ 1,931$ million between 1998 and 2000 (see Figure 2 in the appendix). Although the manufacturing sector is also important in terms of attracting FDI, manufacturing FDI rose by only $\$ 64$ million between 1998 and 2000.

\subsection{Openness to trade}

Measurement issues are potentially a problem for all analytical work, although more acute for openness variables. Since it still appears to be difficult to find reliable systematic data on trade policies across countries, many papers, including Dollar and Kraay (2001), have instead simply included trade volumes (exports plus imports as a share of GDP) as a measure of openness. For our particular purpose of looking at the impact of openness in different sectors on FDI, we also adhere to this useful but imperfect measure. Kandiero and Wadhawan (2003) provide a detailed discussion on openness to trade and measurement problems associated with this variable. We use the economy-wide international trade taxes data to test if our economy-wide openness variable is robust. In this paper we use the terms 'openness' and 'liberalisation' interchangeably in the context of trade.

Turning to data on openness in Africa, mineral-rich countries such as the Congo Republic, Equatorial Guinea and Sao Tome, and smaller economies such as Lesotho, Mauritius, Seychelles and Swaziland are ranked as the most open economies in Africa using our measure of openness (see Table 1 in the appendix). The two most popular FDI destinations, South Africa and Morocco, are ranked 27 and 22 respectively out of the 50 countries. Since the 1980s, most African countries have liberalised unilaterally through structural adjustment programmes, as well as through regional arrangements and multilateral systems such as the World Trade Organization (WTO). It is important to note that in Africa in the last 10 years, trade in services has increased substantially, despite the fact that trade in Africa has been marginalised in the last two decades ${ }^{7}$. Currently, trade in services makes up a quarter of all cross-border trade and a significant portion of all sales by multinational firms (Hoekman \& Mattoo, 2000). Although the increase in trade in the services sector is a positive development, barriers to trade in the services sector remain an obstacle in the promotion of FDI. Therefore, effective liberalisation in the services sector is expected to yield substantial gains (Hodge, 2002: 221). As a precondition, liberalisation in the services sector should be accompanied by effective regulation to ascertain that market failures and infrastructures are addressed.

As mentioned in the previous section, FDI to the manufacturing sector seems to have tapered off. However, barriers such as transportation costs and rules of origin could encourage firms to set up their plants in Africa motivated by "protection jumping". As a caveat, this motivation may adversely affect the depth of their production activities in the host country, although it has the potential to increase domestic sales (Kumar, 2002: 33).

\section{3}

\section{Research methodology and data definition}

\subsection{Model specification}

This study adopts the econometric methodology followed by many cross-country studies such as Barro (1991). The empirical work is applied to a panel of 50 African countries observed over four periods: 1980-1985, 1985-1990, 1990-1995 and 1995-2001. Most of the data are from World Development Indicators (World Bank, 2002). Using panel data makes meaningful empirical research possible even in a case of data limitations such as restricted time frames or missing data, inhibiting factors noted by Barro (1991) and Xavier Sala-i-Martin (1994). Further, the time-dimension of the panel is fairly small in comparison to the number of countries, which helps to avoid some of the business-cycle complications that may arise in time series data. 
We estimate the following equations:

$F_{\mathrm{it}}=\beta_{1}+\beta_{2} \eta_{\mathrm{it}}+\beta_{3} X_{\mathrm{it}}+e_{\mathrm{it}} \cdots$

$F_{\text {it }}=\beta_{1}+\beta_{2} \eta_{\text {it }}+\beta_{3} X_{\text {it }}+\pi_{\text {it }}+z_{\text {it }}$.

where,

$F_{\text {it }}=$ FDI in the $\mathrm{i}^{\text {th }}$ country and $\mathrm{t}$ time periods

$\eta_{i t}=$ measures of openness (where $\mathrm{i}$ is economy-wide openness, openness in the manufacturing sector, openness in the services sector and openness in the primary sector)

$X_{\text {it }}=$ a vector of other determinants of FDI (Taxes on Investment, Infrastructure, Wages, Real Effective Exchange Rate, Market Size and Corruption)

$e_{\mathrm{it}}$ and $z_{\mathrm{it}}=$ error terms

$\pi_{\mathrm{it}}=$ country special effects.

Our estimation starts with a simple pooling method that employs the OLS estimation technique (equation 1). In this model, we do not take into consideration $\pi_{\mathrm{it}}$, unobservable country special effects, which are time-invariant and account for any country-specific effects not included in $\mathrm{X}$ (equations 2). A rejection of the poolability test (F-test) will imply preference of the Fixed Effects method. Considering that many African countries have data limitations in terms of time span and endogeneity issues, which are potential problems in cross-country analysis, the Fixed Effects approach may yield unbiased results. In order to avoid the potential bias associated with this approach, we use the one-step generalised method of moments (GMM) estimator derived by Arellano and Bond (1991). The one-step GMM's robust results are derived from the use of first-differences to remove the country-specific effects that are part of the error term. The instrumental variable estimation, where the instruments are the lagged explanatory variables (in differences) and the dependent variable in level lagged twice, deals with the presence of endogeneity ${ }^{8}$. The dynamic nature of the model and use of the first difference and instruments remove the two inconsistencies of incorrect treatment of country-specific effects and endogeneity.

\subsection{Data definition}

Openness to trade is defined as ((imports + exports)/ GDP) for the whole economy and separately for three sectors (primary, manufacturing and services). Taxes on international trade are import duties, export duties, profits of export or import monopolies, exchange profits and exchange taxes. The expectation is that a less restrictive trade policy environment will attract more FDI. Foreign Direct Investment (FDI) is the net inflow of investment to acquire a lasting management interest (10 per cent or more of voting stock). FDI business enterprises are those that operate in a country other than that of the investor. Investment tax is tax on income, profits and capital gains (per cent of total taxes). This is a fiscal incentive offered by the host country to attract FDI. The tax incentive can also be viewed as a way of subsidizing the cost of capital. Infrastructure (roads) represents roads, and is taken as $1000 \mathrm{~km}$ per 1 million inhabitants. The availability of good infrastructure in a host country potentially favours FDI. Kumar (2002) finds that the positive benefits of good infrastructure are more pronounced in developing countries. Wages represent real wages and salaries in millions adjusted for the quality of labour ${ }^{9}$. Low cost of labour may give the host country an advantage over other countries in terms of attracting FDI (Wheeler \& Mody, 1992). This issue is still open for investigation in the case of Africa.

Real effective exchange rate (REER) measures the value of currency against a weighted average of several foreign currencies divided by a price deflator or index of cost. Exchange rate appreciation may crowd out exports, which in turn could discourage FDI if the motive is to use the host country to produce and then export the goods. Market size captures Gross Domestic Product (GDP) per capita Purchasing Power Parity (PPP) adjusted. GDP is measured as the sum of the gross value added by all resident and non-resident producers in the economy plus any taxes and minus any subsidies not included in the value of the products. GDP is calculated without making deductions for depreciation of fabricated assets or for depletion and degradation of 
natural resources. Value added is the net output of a sector after adding up all outputs. The International Standard Industrial Classification (ISIC) determines the value added. The GDP is converted to international dollars using the PPP rates. GDP per capita is GDP divided by midyear population. Growth rates are calculated as annual averages and represented as percentages. Market size is important when FDI is marketseeking. The data source for all these variables is World Development Indicators 2002 (World Bank, 2002).

The variable capturing corruption represents the degree of corruption in government. ${ }^{10}$ Corruption is defined as demands for special payments and bribes in connection with import and export licenses, exchange controls, tax assessment or loans. The data range is from 0 to 6 , with 0 being the highest corruption and 6 the lowest corruption. The data source is the International Country Risk Guide (ICRG), a monthly publication by the Political Risk Services. In general, countries that are perceived to be corrupt attract less FDI (Wei, 2000). Table 3 in the appendix shows a correlation matrix of all the variables defined here.

\section{4}

\section{Empirical analysis}

Table 1 gives the econometric results of our model through various estimation techniques. The Wald Joint procedure in Table 1 tests the significance of all the variables except the constant term. This procedure could be thought of as the equivalence of the F-test.

Table 1

Regression results, 1980-2001, dependent variable FDI to GDP

\begin{tabular}{|c|c|c|c|c|c|c|c|}
\hline & OLS & $\begin{array}{l}\text { Fixed } \\
\text { effects }\end{array}$ & GMM1 & GMM2 & GMM3 & GMM4 & GMM5 \\
\hline Constant & -0.6512 & & 7.684 & 4.350 & 29.3013 & 29.3860 & 34.1322 \\
\hline Openness & $\begin{array}{c}0.0363 * \\
(0.0088)\end{array}$ & $\begin{array}{c}0.0354 * \\
(0.0042)\end{array}$ & $\begin{array}{c}0.0520^{*} \\
(0.0161)\end{array}$ & & & & \\
\hline $\begin{array}{l}\text { Openness } \\
\text { (services) }\end{array}$ & & & & $\begin{array}{c}0.1161^{*} \\
(0.0478)\end{array}$ & & & \\
\hline $\begin{array}{l}\text { Openness } \\
\text { (manufacturing) }\end{array}$ & & & & & $\begin{array}{c}0.0098 \\
(0.0353)\end{array}$ & & \\
\hline $\begin{array}{l}\text { Openness } \\
\text { (primary) }\end{array}$ & & & & & & $\begin{array}{c}-0.0586^{*} \\
(0.0059)\end{array}$ & \\
\hline Trade tax & & & & & & & $\begin{array}{c}-0.1142^{*} \\
(0.0492)\end{array}$ \\
\hline $\begin{array}{l}\text { Tax on } \\
\text { investment }\end{array}$ & $\begin{array}{c}-0.1198^{*} \\
(0.0343)\end{array}$ & $\begin{array}{c}0.0113 \\
(0.0310)\end{array}$ & $\begin{array}{l}-0.0417^{*} \\
(0.0141)\end{array}$ & $\begin{array}{r}-0.02593^{* *} \\
(0.01302)\end{array}$ & $\begin{array}{r}-0.0595^{*} \\
(0.0115)\end{array}$ & $\begin{array}{c}-0.0867^{*} \\
(0.0159)\end{array}$ & $\begin{array}{l}-0.1198^{*} \\
(0.034)\end{array}$ \\
\hline Log REER & $\begin{array}{l}-5.683^{* * *} \\
(3.355)\end{array}$ & $\begin{array}{l}-3.731 \\
(2.915)\end{array}$ & $\begin{array}{r}-2.8160 \\
(2.111)\end{array}$ & $\begin{array}{c}-2.0855^{* * *} \\
(1.206)\end{array}$ & $\begin{array}{l}-5.3271 \\
(3.802)\end{array}$ & $\begin{array}{l}-5.9469^{*} \\
(2.040)\end{array}$ & $\begin{array}{l}-5.6826^{* * *} \\
(3.355)\end{array}$ \\
\hline Log road & $\begin{array}{c}1.3908^{*} \\
(0.3303)\end{array}$ & $\begin{array}{c}0.1708 \\
(0.2548)\end{array}$ & $\begin{array}{l}0.3191^{* *} \\
(0.1871)\end{array}$ & $\begin{array}{c}0.2351 \\
(0.2787)\end{array}$ & $\begin{array}{c}0.8953^{*} \\
(0.2953)\end{array}$ & $\begin{array}{c}1.2915^{*} \\
(0.3732)\end{array}$ & $\begin{array}{l}1.3901^{*} \\
(0.3303)\end{array}$ \\
\hline Wages & $\begin{array}{c}-0.00014 \\
(0.0001)\end{array}$ & $\begin{array}{c}-0.0003 \\
(0.0003)\end{array}$ & $\begin{array}{l}-0.000045 \\
(0.0002)\end{array}$ & $\begin{array}{l}-0.0001^{*} \\
(0.0003)\end{array}$ & $\begin{array}{c}0.0006^{* *} \\
(0.0002)\end{array}$ & $\begin{array}{r}0.0006^{*} \\
(0.0002)\end{array}$ & $\begin{array}{c}-0.0001 \\
(0.0001)\end{array}$ \\
\hline
\end{tabular}




\begin{tabular}{|c|c|c|c|c|c|c|c|}
\hline Market size & $\begin{array}{l}-0.0426 \\
(0.1942)\end{array}$ & $\begin{array}{l}-0.1075 \\
(0.4439)\end{array}$ & $\begin{array}{c}0.5517^{*} \\
(0.1312)\end{array}$ & $\begin{array}{c}0.5451^{*} \\
(0.09297)\end{array}$ & $\begin{array}{c}-0.4654^{*} \\
(0.1952)\end{array}$ & $\begin{array}{l}-0.1370 \\
(0.1261)\end{array}$ & $\begin{array}{l}-0.0426 \\
(0.19422)\end{array}$ \\
\hline Corruption & $\begin{array}{l}-0.2158 \\
(0.2410)\end{array}$ & $\begin{array}{c}0.0341 \\
(0.3776)\end{array}$ & $\begin{array}{l}-0.1301 \\
(0.2043)\end{array}$ & $\begin{array}{c}0.08165 \\
(0.2947)\end{array}$ & $\begin{array}{l}0.4117^{*} \\
(0.159)\end{array}$ & $\begin{array}{c}0.5142^{*} \\
(0.1193)\end{array}$ & $\begin{array}{l}-0.2159 \\
(-0.2410)\end{array}$ \\
\hline $\begin{array}{l}\text { Number of } \\
\text { observations }\end{array}$ & 204 & 204 & 204 & 204 & 204 & 204 & 204 \\
\hline Wald joint & & $\begin{array}{c}633.3 \\
{[0000]^{* *}}\end{array}$ & $\begin{array}{c}4784 \\
{[0.000]^{* *}}\end{array}$ & $\begin{array}{c}194 \\
{[0.000]^{* *}}\end{array}$ & $\begin{array}{c}557 \\
{[0000]^{*}}\end{array}$ & $\begin{array}{c}17.37 \\
{[0.015]^{*}}\end{array}$ & $\begin{array}{c}537 \\
{[0.000]^{*}}\end{array}$ \\
\hline Wald dummy & & $\begin{array}{c}348.5 \\
{[0.000]^{* *}}\end{array}$ & $\begin{array}{l}0.8627 \\
{[0.353]}\end{array}$ & $\begin{array}{c}0.825 \\
{[0.364]}\end{array}$ & $\begin{array}{c}2.479 \\
{[0.115]}\end{array}$ & $\begin{array}{c}8.261 \\
{[0.004]^{* *}}\end{array}$ & $\begin{array}{c}3.568 \\
{[0.059]}\end{array}$ \\
\hline AR 1 test & & $\begin{array}{c}-0.6562 \\
{[0.512]}\end{array}$ & $\begin{array}{c}-0.8493 \\
{[0.396]}\end{array}$ & $\begin{array}{l}-1.407 \\
{[0.159]}\end{array}$ & $\begin{array}{c}1.026 \\
{[0.305]}\end{array}$ & & $\begin{array}{l}-1.269 \\
{[0.204]}\end{array}$ \\
\hline AR 2 test & & $\begin{array}{c}0.8388 \\
{[4.02]}\end{array}$ & $\begin{array}{c}0.6085 \\
{[0.543]}\end{array}$ & $\begin{array}{c}1.398 \\
{[0.162]}\end{array}$ & $\begin{array}{c}-0.2454 \\
{[0.806]}\end{array}$ & & $\begin{array}{c}1.378 \\
{[0.168]}\end{array}$ \\
\hline
\end{tabular}

Notes:

${ }^{*} 1 \%$ significance level, $* * 5 \%$ significance level, $* * * 10 \%$ significance level

The four periods of estimation are 1980-85, 1985-90, 1990-95 and 1995-2001

Pooling Test: $F(6,44)=3.843[0.004]$

OLS DW $=1.96$

The Fixed Effects, GMM1 and GMM2 models are significant at the 5 per cent significance level, while GMM3, GMM4 and GMM5 are significant at 1 per cent level. The absence of first and second order autocorrelation in the Fixed Effects and GMM model residuals implies that the estimates are consistent. From the actual results, the GMM estimation results are our preferred choice as the estimations yield superior results.

In our first two models, OLS and Fixed Effects, the economy-wide openness coefficient is statistically significant at the 1 per cent level. The rejection of the poolability test in the OLS model reveals the presence of fixed effects. Controlling for fixed effects, however, does not yield better results. This could mean that other problems, for example endogeneity, could be present in this cross-country analysis. The GMM1 estimates yield better results than the previous models, with a statistically significant coefficient of magnitude 0.0520 (tables 1 and 2). An increase of 10 per cent in the economy-wide openness will increase the FDI to GDP ratio by 13 per cent. This supports the argument that countries that are more open to trade are likely to attract foreign firms. Asiedu (2002), Singh and Jun (1995) and Edwards (1990) also find similar results. In the same model, economic variables such as investment tax and wages have a negative impact on FDI, while infrastructure and market size have a significantly positive impact on FDI. Generally, only in the case of export-oriented FDI does cheap labour in terms of lower wages work as an incentive (Wheeler \& Mody, 1992).

The GMM2 model replaces economy-wide openness with openness in the services sector variable. The positive coefficient, 0.1161 , is also significant at the 1 per cent level. From Table 2, an increase in openness in the services sector by 10 per cent will increase the FDI to GDP ratio by 7 per cent. Based on our discussion in the previous sections, FDI to the services sector has increased (this type of FDI is mainly in the form of commercial presence or Mode 3 (Hodge, 2002)). Changes in regulation in the financial and communication sectors could have been the cause of these positive effects. Since we cannot separate the effects in this case, another study should be carried out focusing solely on services and regulation. In spite of these positive results, the sector has more barriers to trade than do other sectors such as primary and manufacturing. Therefore, these results tell us that further liberalisation in the services 
sector is likely to yield significant gains in terms of attracting FDI. In the same model, exchange rate appreciation and investment tax have a significantly negative impact on FDI, while market size has maintained a positive coefficient.

In the case of the GMM3 model, more openness in the manufacturing sector does not seem to have any significant impact on the FDI to GDP ratio. One of the explanations for this result could be that most of the barriers to trade affecting FDI in the manufacturing sector seem to have been phased out. In this regard, more openness in this sector may not have a major impact. In this model, variables such as corruption, wages, infrastructure and investment tax are also important. A study by Wei (2000) supports the argument that less corruption may attract FDI.

Table 2

Openness elasticities

\begin{tabular}{|l|c|c|c|c|c|c|c|c|c|}
\hline $\begin{array}{l}\text { Openness } \\
\text { variables }\end{array}$ & Mean & GMM1 & $\begin{array}{c}\text { GMM1 } \\
\text { elasticity }\end{array}$ & GMM2 & $\begin{array}{c}\text { GMM2 } \\
\text { elasticity }\end{array}$ & GMM4 & $\begin{array}{c}\text { GMM4 } \\
\text { elasticity }\end{array}$ & GMM5 & $\begin{array}{c}\text { GMM5 } \\
\text { elasticity }\end{array}$ \\
\hline Openness & 77.308 & 0.0520 & 1.30652 & & & & & & \\
\hline $\begin{array}{l}\text { Openness } \\
\text { services }\end{array}$ & 19.773 & & & 0.1161 & 0.7461 & & & & \\
\hline $\begin{array}{l}\text { Openness } \\
\text { primary }\end{array}$ & 3.7692 & & & & & -0.0586 & -0.07178 & & \\
\hline Trade tax & 24.692 & & & & & & & -0.1142 & -0.9165 \\
\hline
\end{tabular}

In the GMM4 model, primary sector openness is statistically significant at the 1 per cent level but has a negative coefficient, -0.0586 . An increase of 10 per cent in openness in the primary sector will reduce the FDI by 0.7 per cent. The pattern of data in the previous sections shows that while FDI to the services sector has increased, FDI to the primary sector has decreased. In Figure 1 in the appendix, FDI to the primary sector can be seen to have declined significantly from $\$ 5$ billion in 1998 to $\$ 2$ billion in 2000, while most of the African countries have opened their economies. It is possible that efficiency gains and increased investments from increased openness in sectors such as services may enable a country to support some of the activities in the primary sectors, reducing some investment by foreign firms. It is also probable that the sign could be reflecting other interactions in the function. In this model, investment tax and real effective exchange rate are statistically significant at the 1 per cent level and negatively associated with FDI to GDP, while an increase in wages is also statistically significant but has a positive association. In this model, an improvement in the corruption index by 1 per cent will increase FDI to GDP by 60 per cent.

The GMM5 model includes the international trade tax variable to test the robustness of our economy-wide openness variable. This variable is used because trade taxes are also considered as an important indicator of openness. The results in tables 1 and 2 indicate that a reduction in trade taxes by 10 per cent will increase the FDI to GDP ratio by 9 per cent. Loree and Guisinger (1995) also find a negative relationship between trade taxes and FDI. The elasticity of the economy-wide variable is 13 per cent, indicating that the two variables are consistent. Based on the regression results, therefore, increased openness to trade will increase the FDI to GDP ratio in African countries.

\section{Regional dummies}

Our study attempts to divide the countries into regions (i.e. Middle East and North Africa (MENA) and Southern Africa Development Community (SADC)) to identify some of the differences between these sectors. These areas may differ in terms of identity, culture of doing 
business, geography, size of countries and size of their economies. Specifically, MENA countries have tended to view sub-Saharan countries as backward in terms of integration. Interestingly, after these regions have been separately controlled for, the estimate of the regional dummy is not statistically significant (see table 4 in the appendix). However, stable economic variables such as openness, investment tax, exchange rate, infrastructure and market size remain the key determinants of FDI, regardless of the region.

\section{Political instability}

This study also includes the political instability variable as a proxy for how the political climate many impact FDI. A study by De Soto (2000: 69) makes a strong case for the need for political awareness in managing capital. The estimate for political instability is not statistically significant, meaning that this variable does not seem to pose a major risk in terms of FDI flows to Africa. This result is rather surprising, but is born out by the evidence of countries like Angola, an oil-exporting country, which has experienced political instability for many years and yet seen an increase in FDI. A plausible explanation is that FDI to Angola is highly profitable and the return even after adjusting for risk is still quite substantial. Overall, however, the empirical relationship between political instability and FDI is still unclear. On one hand, Schneider and Frey (1985) find a positive relationship between FDI and political instability and on the other, Asiedu (2002), Hausmann and Fernandez-Arias (2000) and Jaspersen, Aylward and Knox (2000) find no such link. Nonetheless, we cannot ignore the importance of political climate in investment decisions if Africa would like to "Walk the Walk" (Loots, 2005: 19). After controlling for political instability, estimates in the new model indicate that economic variables such as openness, tax incentives and market size are key determinants of FDI.

\section{5}

\section{Conclusions and recommendations}

FDI to Africa is affected by many factors, including market size, investment taxes, corruption and wages. The principal goal of this study was to investigate the impact of openness to trade in the whole economy as well as its different sectors. The FDI to GDP ratio responds well to increased openness in the whole economy and in the services sector in particular. Further reduction in tariff and nontariff barriers such as licensing or cumbersome procedures will increase FDI. Increasing market access in the area of services is high on Africa's agenda. Due to high protection in the services sector, gains from further liberalisation are expected to be high. Beyond this study, a more liberal financial system, for example, is likely to attract more foreign banks, leading to more FDI. As a caveat, liberalisation in the services sector should be accompanied by effective regulation to ascertain that issues related to market failure and infrastructure are addressed. In Southern Africa, to date, only South Africa, Tanzania, Zambia and Zimbabwe have competition policies and institutions to support further liberalisation in the services sector (Hartzenberg, 2002). To improve access in the services sector, the issue of temporary movement of natural persons (Mode 4) should also be taken into consideration. Currently cumbersome visa processes and precarious contracts block movement of labour in sectors such as construction, where most African countries have a comparative advantage. Movement of labour should be encouraged to attract more skilled workers. The removal of these barriers is likely to increase competitiveness in the services sector. All these avenues offer areas for further research.

Greater openness is one route for Africa to catch up with the rest of the world's developing countries in attracting FDI. Even though opening the services sector seems to influence the FDI to GDP ratio more than opening the primary and manufacturing sectors, economy-wide openness measures give the best results. In addition to openness, other factors such as investment tax, wages, infrastructure, institutional frameworks and regulation should also be taken into consideration if Africa is to attract more FDI.

For future research, it would be interesting to conduct a similar exercise using more disaggregated data such as mining, forestry, financial services, etc. 


\section{Endnotes}

1 The views and opinions expressed in this paper are those of the authors and do not necessarily represent the views and polices of the National Treasury. The authors are grateful for the useful comments and suggestions made by the two anonymous referees. We gratefully acknowledge the comments of participants at the Economic Society of Southern Africa 2003 Annual Conference, Cape Town, South Africa. We would also like to thank Christine Mugoya for her research support.

2 Even though Angola is considered politically unstable, the high returns from oil have attracted FDI flows.

3 It is beyond the scope of this paper to review the vast literature on the FDI-growth relationship and the determinants of FDI. The interested reader should refer to De Mello (1997) for a comprehensive survey of the link between FDI and growth as well as for further evidence on the FDIgrowth relationship. The author concludes that the impact of FDI on growth will depend on the scope for efficiency spillovers to domestic firms, by which FDI leads to increasing returns in domestic production, and increases in the value-added content of FDI-related production.

4 For more details see Asiedu (2002), Hausmann and Fernandez-Arias (2000), Gastanaga, Nugent and Pashamova (1998), Singh and Jun (1995) and Edwards (1990).

5 See Casselli, Esquivel and Leffort (1996) for a detailed discussion.

6 The recent increase in FDI from South Africa to other parts of Africa has been both marketrent-seeking and market-seeking (Akinboade \& Lalthapersad, 2005). FDI ranges from finance, telecommunications, mining and retail trade to transport

7 According to the WTO, Africa only accounted for 2.6 per cent of global exports in 2004, a decline from 3.1 per cent in 1990 .

8 This methodology was first suggested by Anderson and Hsiao (1981) and later developed further by Arellano and Bond (1991).

9 The adjustment is carried out by regressing the variable on gross enrolment for secondary and tertiary education.

10 Unfortunately the (ICRG) index captures only government corruption; a more comprehensive index containing both government and private sector corruption would have been better.

\section{References}

1 AKINBOADE, O. \& LALTHAPERSADPILLAY, P. (2005) "South Africa and the new partnership for Africa's development: Economic spin-offs and linkages", South Africa Journal of Economics, 73(2): 243-268.

2 ASIEDU, E. (2002) "On the determinants of foreign direct investment to developing countries: Is Africa different?", World Development, (30): 107-119.

3 ANDERSON, T.W. \& HSIAO, C. (1981)

"Estimation of dynamic models with error components", Journal of the American Statistical Association, (76): 598-606.

4 ARELlANO, M. \& BOND, S. (1991) "Some tests of specification for panel data: Monte Carlo evidence and an application to employment equations", Review of Economics Studies, (58): 227297.

5 BARRO, R.J. (1991) "Economic growth in a cross-section of countries", Quarterly Journal of Economics, (106): 407-443.

6 BASU, A. \& SRINIVSAN, K. (2002) Foreign direct investment in Africa: Some case studies, IMF Working Paper Number WP/02/61, IMF: Washington DC.

7 CASSELLI, F; ESQUIVEL, G. \& LEFORT, F. (1996) "Reopening the convergence: A new look at cross-country growth empirics", Journal of Economic Growth, 1: 363-389.

8 DE MELLO, L.R. (1997) "Foreign direct investment in developing countries and growth: A selective survey", Journal of Development Studies, 34(1): 1-34.

9 DE SOTO, H. (2000) The Mystery of Capital: Why Capitalism Triumphs in the West and Fails Everywhere Else, Basic Books: New York.

10 DOLLAR, D. \& KRAAY, A. (2001) "Trade, growth and poverty", World Bank Working Paper No. 2587, World Bank: Washington DC.

11 DUNNING, J. (1993) Multinational Enterprises and the Global Economy, Wokingham: Addison.

12 EDWARDS, S. (1990) "Capital flows, foreign direct investment, and debt-equity swaps in developing countries", NBER Working Paper No. 3497, NBER: Cambridge.

13 GASTANAGA, V.J.B.; NUGENT, J.B. \& PASHAMOVA, B. (1998) "Host country reforms and FDI inflows: How much difference do they make?", World Development, 26: 1299-1314.

14 HARTZENBERG, T. (2002) "Competition policy in SADC", presented at TIPS workshop on Global Integration, Sustainable Development, and the 
Southern African Economy. Johannesburg: Trade and Industrial Policy Secretariat.

15 HAUSMANN, R. \& FERNANDEZ-ARIAS, E. (2000) "The new wave of capital inflows: Sea change or just another title?", Inter-American Development Bank Working Paper No. 417, InterAmerican Development Bank, Washington DC.

16 HOEKMAN, B. \& MATTOO, A. (2000) "Services, economic development and the next round of negotiations on services", Journal of International Development, 12(28): 3-96.

17 HODGE, J. (2002) "Liberalizing of trade in services in developing Countries," in Hoekman, B., English, P. \& Matoo, A. (eds.) Development, Trade and the WTO: A Handbook, World Bank: Washington DC.

18 JASPERSEN, F.Z; AYLWARD, A \& KNOX, A.D. (2000) "The effects of risk on private investment: Africa compared with other developing areas", in Collier, P. \& Pattillo, C. (eds.) Investment and Risk in Africa, St Martin's Press: New York.

19 KANDIERO T. \& WADHAWAN, S. (2003) "Institutional quality, openness and investment in Africa," South African Journal of Economic and Management Sciences, 6: 346-368.

20 KUMAR, N. (2002) Globalization and the Quality of Foreign Direct Investment, Oxford University Press: Oxford.

21 LOREE, D.W. \& GUISINGER, S.E. (1995) "Policy and non-policy determinants of U.S. equity investment," Journal of Business Studies, (26): 229-242.
22 LOOTS, E. (2005) "Nepad and capital flows initiative: Can Africa walk the walk?", South Africa Journal of Economics, 73(1): 1-20.

23 MARKUSEN, J.; RUTHERFORD, T. \& TARR, D. (2002) "Foreign direct investment in services and domestic market expertise", Policy Research Working Paper No. 2413, World Bank: Washington DC.

24 SALA-I-MARTIN, X. (1994) "Cross-sectional regressions and the empirics of economic growth", European Economic Review, (38): 739-747.

25 SCHNEIDER, F. \& FREY, B.S. (1985) "Economic and political determinants of foreign direct investment," World Development, 13 (2): 161-175.

26 SINGH, H. \& JUN, K. (1995) "Some new evidence on determinants of foreign direct investment in developing countries", World Bank Policy Research Working Paper No. 1531, World Bank: Washington DC.

27 TODARO, M.P. (2002) Economic Development, Addison Wesley Longman: New York.

28 UNCTAD (2002) World Investment Report 2002, UNCTAD: Geneva.

29 WEI, S.J. (2000) "How taxing is corruption on international investors?", Review of Economics and Statistics, 82(1): 1-11.

30 WHEELER, D. \& MODY, A. (1992) "International investment location decisions: the case of U.S. firms", Journal of International Economics, (33): 57-6.

31 WORLD BANK (2002), World Development Indicators, CD-Rom. 


\section{Appendix A}

\section{Figure 1}

FDI Net inflows, 2001, (millions of US\$)

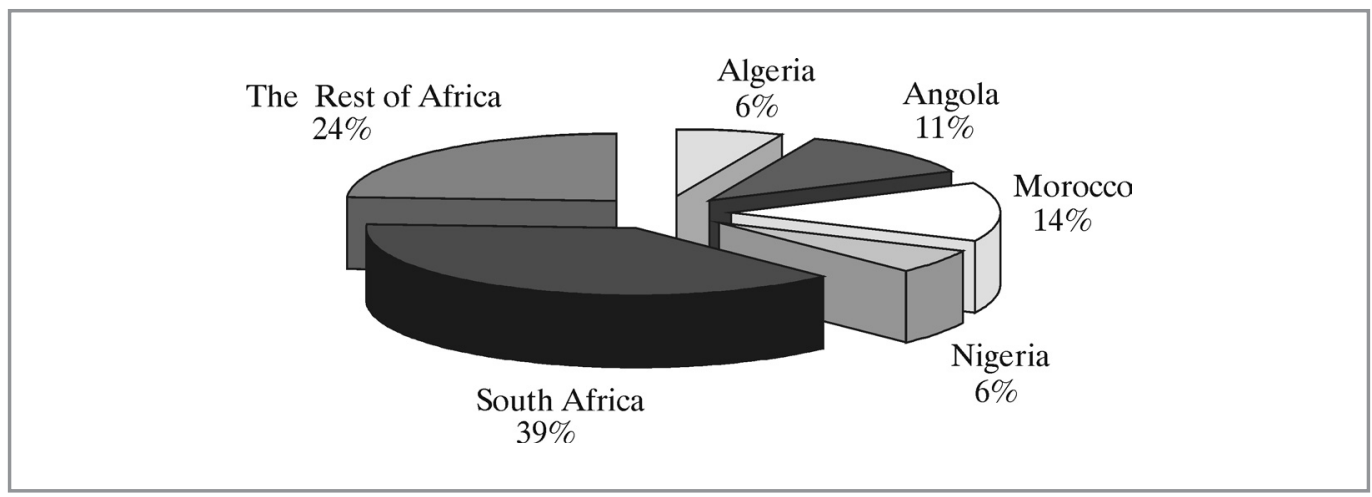

Source: Authors' calculations based on data from World Bank, 2002

Figure 2

FDI to Africa by sector, 1998 and 2000

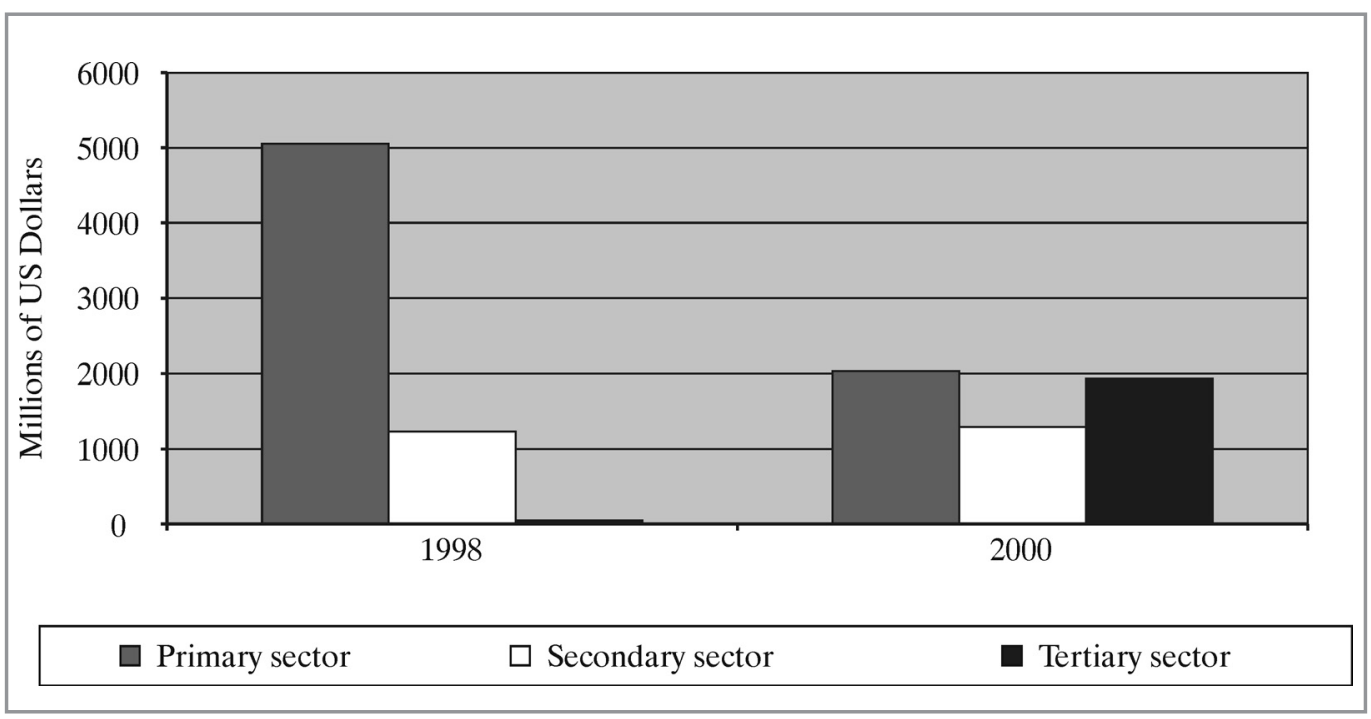

Source: Authors' calculations based on data from UNCTAD, 2002 
Table 1

Openness to trade and ranking in Africa, 1995-2001

\begin{tabular}{|c|c|c|c|c|c|}
\hline Country & Openness & Rank & Country & Openness & Rank \\
\hline Equatorial Guinea & 173 & 1 & Malawi & 63 & 21 \\
\hline Swaziland & 173 & 1 & Kenya & 63 & 21 \\
\hline Seychelles & 153 & 2 & Guinea-Bissau & 63 & 21 \\
\hline Lesotho & 129 & 3 & Comoros & 63 & 21 \\
\hline Mauritius & 129 & 3 & Morocco & 62 & 22 \\
\hline Congo, Rep. & 123 & 4 & Madagascar & 56 & 23 \\
\hline Angola & 119 & 5 & Algeria & 55 & 24 \\
\hline Sao Tome and Principe & 118 & 6 & Mozambique & 55 & 24 \\
\hline Gambia, The & 115 & 7 & Congo, Dem. Rep. & 53 & 25 \\
\hline Eritrea & 112 & 8 & Chad & 53 & 25 \\
\hline Namibia & 107 & 9 & Cameroon & 51 & 26 \\
\hline Djibouti & 103 & 10 & Guinea & 50 & 27 \\
\hline Gabon & 100 & 11 & South Africa & 50 & 27 \\
\hline Mauritania & 96 & 12 & Benin & 47 & 28 \\
\hline Tunisia & 89 & 13 & Tanzania & 44 & 29 \\
\hline Ghana & 89 & 13 & Egypt, Arab Rep. & 43 & 30 \\
\hline Cote d'Ivoire & 84 & 14 & Sierra Leone & 42 & 31 \\
\hline Nigeria & 82 & 15 & Burkina Faso & 41 & 32 \\
\hline Botswana & 79 & 16 & Ethiopia & 41 & 32 \\
\hline Togo & 79 & 16 & Uganda & 40 & 33 \\
\hline Cape Verde & 78 & 17 & Niger & 39 & 34 \\
\hline Zambia & 73 & 18 & Central African Republic & 36 & 35 \\
\hline Zimbabwe & 70 & 19 & Rwanda & 31 & 36 \\
\hline Senegal & 70 & 19 & Burundi & 28 & 37 \\
\hline Mali & 64 & 20 & Sudan & 27 & 38 \\
\hline
\end{tabular}


Table 2

FDI to Africa, 1990-2001 (US\$ millions)

\begin{tabular}{|c|c|c|c|c|c|c|}
\hline Foreign direct investment, & 1990 & 1995 & 2000 & 2001 & 2000 & 2001 \\
\hline Net inflows (BoP, current US\$) (mill) & & & & & $\begin{array}{l}\text { \% of } \\
\text { Total }\end{array}$ & $\begin{array}{l}\% \text { of } \\
\text { Total }\end{array}$ \\
\hline Algeria & 0 & 0 & 438 & 1,196 & 5 & 6 \\
\hline Angola & -335 & 472 & 879 & 2,146 & 10 & 12 \\
\hline Benin & 62 & 7 & 64 & 131 & 1 & 1 \\
\hline Botswana & 96 & 70 & 57 & 57 & 1 & 0 \\
\hline Burkina Faso & 0 & 10 & 23 & 26 & 0 & 0 \\
\hline Burundi & 1 & 2 & 12 & 0 & 0 & 0 \\
\hline Cameroon & -113 & 7 & 31 & 75 & 0 & 0 \\
\hline Cape Verde & 0 & 26 & 21 & 1 & 0 & 0 \\
\hline Central African Republic & 1 & 3 & 5 & 8 & 0 & 0 \\
\hline Chad & 9 & 13 & 15 & 80 & 0 & 0 \\
\hline Comoros & 0 & 1 & 1 & 2 & 0 & 0 \\
\hline Congo, Dem. Rep. & -15 & -22 & 23 & 32 & 0 & 0 \\
\hline Congo, Rep. & 7 & -60 & -75 & 59 & -1 & 0 \\
\hline Cote d'Ivoire & 48 & 212 & 235 & 246 & 3 & 1 \\
\hline Djibouti & 0 & 3 & 3 & 3 & 0 & 0 \\
\hline Egypt, Arab Rep. & 734 & 598 & 1,235 & 510 & 14 & 3 \\
\hline Equatorial Guinea & 11 & 127 & 120 & 88 & 1 & 0 \\
\hline Eritrea & - & 0 & 35 & 34 & 0 & 0 \\
\hline Ethiopia & 12 & 14 & 135 & 20 & 2 & 0 \\
\hline Gabon & 74 & -315 & 252 & 200 & 3 & 1 \\
\hline Gambia, The & 0 & 8 & 44 & 36 & 1 & 0 \\
\hline Ghana & 15 & 107 & 110 & 89 & 1 & 0 \\
\hline Guinea & 18 & 1 & 10 & 2 & 0 & 0 \\
\hline Guinea-Bissau & 2 & 0 & 23 & 30 & 0 & 0 \\
\hline Kenya & 57 & 33 & 111 & 5 & 1 & 0 \\
\hline Lesotho & 17 & 275 & 118 & 117 & 1 & 1 \\
\hline Liberia & 0 & 0 & 12 & 13 & 0 & 0 \\
\hline Libya & - & - & - & - & - & - \\
\hline Madagascar & 22 & 10 & 83 & 11 & 1 & 0 \\
\hline Malawi & 23 & 25 & 45 & 58 & 1 & 0 \\
\hline
\end{tabular}




\begin{tabular}{|c|c|c|c|c|c|c|}
\hline Mali & 6 & 111 & 106 & 103 & 1 & 1 \\
\hline Mauritania & 7 & 7 & 9 & 30 & 0 & 0 \\
\hline Mauritius & 41 & 19 & 266 & -48 & 3 & 0 \\
\hline Morocco & 165 & 438 & 201 & 2,658 & 2 & 14 \\
\hline Mozambique & 9 & 45 & 139 & 480 & 2 & 3 \\
\hline Namibia & - & - & - & - & & \\
\hline Niger & 41 & 7 & 19 & 13 & 0 & 0 \\
\hline Nigeria & 588 & 1,079 & 930 & 1,104 & 11 & 6 \\
\hline Rwanda & 8 & 2 & 8 & 5 & 0 & 0 \\
\hline Sao Tome and Principe & 0 & 0 & 2 & 6 & 0 & 0 \\
\hline Senegal & 57 & 32 & 88 & 126 & 1 & 1 \\
\hline Seychelles & 20 & 46 & 25 & 59 & 0 & 0 \\
\hline Sierra Leone & 32 & -2 & 5 & 4 & 0 & 0 \\
\hline Somalia & 6 & 1 & 0 & 0 & 0 & 0 \\
\hline South Africa & - & 1,248 & 969 & 7,162 & 11 & 39 \\
\hline Sudan & 0 & 0 & 392 & 574 & 5 & 3 \\
\hline Swaziland & 30 & 52 & 35 & 21 & 0 & 0 \\
\hline Tanzania & 0 & 120 & 194 & 224 & 2 & 1 \\
\hline Togo & 18 & 26 & 42 & 67 & 0 & 0 \\
\hline Tunisia & 76 & 264 & 752 & 457 & 9 & 2 \\
\hline Uganda & 0 & 121 & 161 & 145 & 2 & 1 \\
\hline Zambia & 203 & 97 & 122 & 72 & 1 & 0 \\
\hline Zimbabwe & -12 & 118 & 23 & 5 & 0 & 0 \\
\hline Total & 2041 & 5458 & 8553 & 18542 & 100 & 100 \\
\hline
\end{tabular}




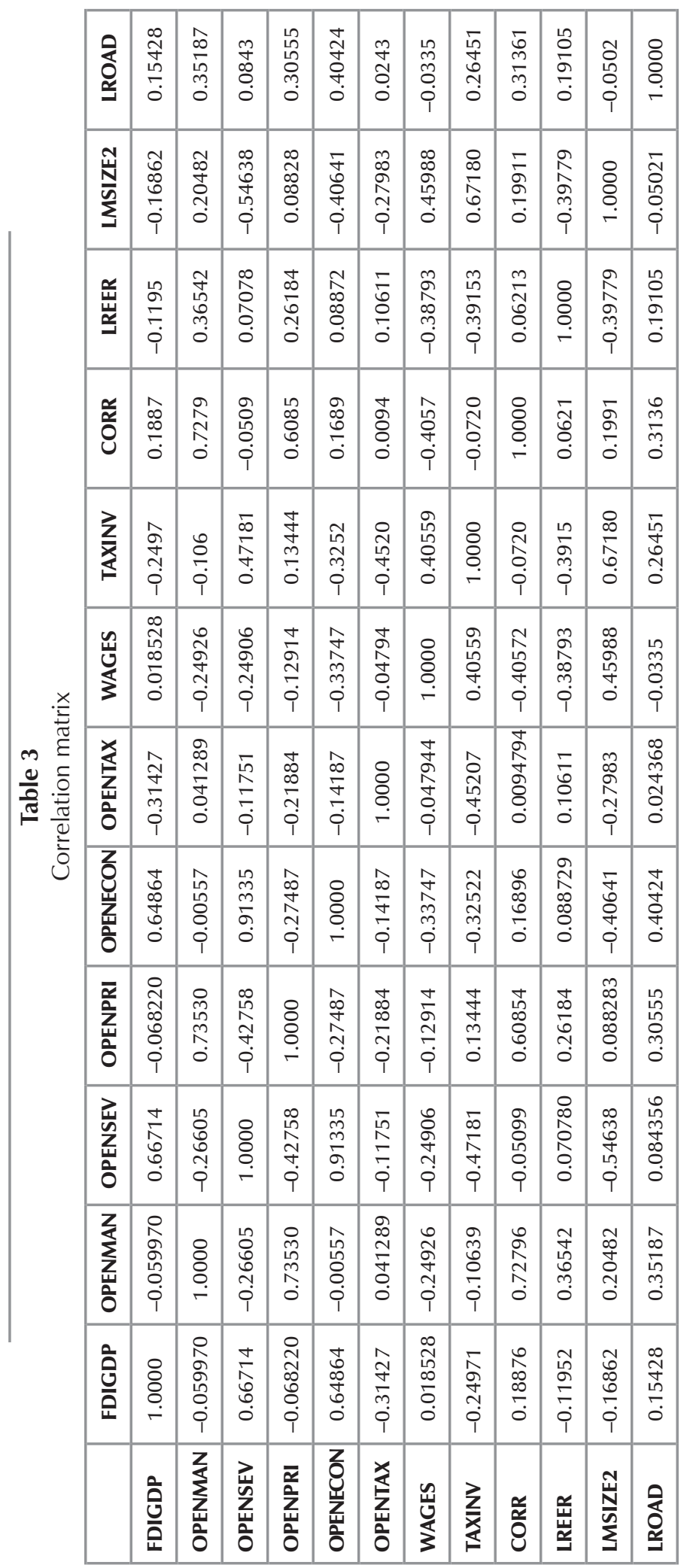


Table 4

Regression results, 1980-2001, dependent variable FDI to GDP

\begin{tabular}{|l|c|c|c|}
\hline & GMM estimates & GMM estimates & GMM estimates \\
\hline Constant & $\begin{array}{c}-0.1301 \\
(0.09208)\end{array}$ & $\begin{array}{c}-0.0920 \\
(0.01794)\end{array}$ & $\begin{array}{c}7.4499 \\
(8.187)\end{array}$ \\
\hline Openness & $0.0315^{*}$ & $0.0335^{*}$ & $0.0539^{*}$ \\
& $(0.0111)$ & $(0.01299)$ & $(0.01714)$ \\
\hline Investment tax & $-0.0369^{*}$ & -0.0429146 & -0.0403572 \\
& $(0.0137)$ & $(0.01791)^{*}$ & $(0.0154)^{*}$ \\
\hline Real exchange rate & -0.6396 & $-0.4507^{*}$ & -2.7236 \\
& $(0.4705)^{*}$ & $(0.09869)$ & $(2.084)^{*}$ \\
\hline Roads & $0.5515^{*}$ & $0.556949^{*}$ & 0.229741 \\
& $(0.0739)$ & $(0.09108)$ & $(0.3001)$ \\
\hline Corruption & $-0.3637^{*}$ & $-0.413875^{*}$ & -0.1089 \\
& $(0.1070)$ & $(0.09272)$ & $(0.2160)$ \\
\hline Market size & $0.4373^{*}$ & $0.412282^{*}$ & 0.5470 \\
& $(0.1660)$ & $(0.07075)$ & $(0.1333)^{*}$ \\
\hline Wages & 0.0001 & $8.17951 \mathrm{e}-005$ & $-3.91218 \mathrm{e}-005$ \\
& $(0.0001)$ & $(5.949 \mathrm{e}-005)$ & $(0.0001)$ \\
\hline Mena dummy & 0.0833 & & -0.0812 \\
& $(0.4148)$ & $(0.1299)$ \\
\hline SADC dummy & & & \\
\hline Political instability & & -0.367054 & \\
& & & \\
\hline
\end{tabular}

$* 1 \%$ significance level, $* * 5 \%$ significance level, $* * * 10 \%$ significance level 